\title{
Performance of Reclaimed Asphalt Pavement (RAP) as a Replacement of Fine Aggregate in Concrete
}

\author{
Sani Mohammed Bida ${ }^{1,3^{*}}$, MuktarNuhu Danraka ${ }^{1,2}$, Jiya Mohammed Ma'ali ${ }^{3}$ \\ ${ }^{1}$ Department of Civil Engineering, Faculty of Engineering, Universiti Putra Malaysia, 43400 Selangor, Malaysia \\ ${ }^{2}$ Department of Civil Engineering, Faculty of Engineering, Abubakar Tafawa Balewa University, Bauchi, Nigeria \\ ${ }^{3}$ Department of Civil Engineering, School of Engineering Technology, Federal Polytechnic Bida, Nigeria
}

\begin{abstract}
Road pavement failure is a challenging phenomenon for road maintenance agencies due to increase vehicular traffic. In developing countries, some pavements fail even before the completion and handing over site.During maintenance, the material removed from failed portions is regarded as waste and are disposed-off along road sides or in dumps. This paper investigates the possibility of recycling the material removed known as Reclaimed Asphalt Pavement (RAP) in concrete specimens as partial replacement of aggregate.RAPwas used to replace the fine aggregates from $0-100 \%$ at $20 \%$ intervals. Water absorption, density and compressive strength tests were carried out.Increased workability, less water absorption and compressive strength of $75 \%$, 25\%and 28.4 MPawere achieved at $100 \%$ replacement, $20 \%$ and $40 \%$ replacement levels respectively
\end{abstract}

Keywords: compressive strength, density, fine aggregate, Reclaimed Asphalt Pavement, workability

\section{Introduction}

Asphaltic concrete is a black sticky bituminous material use in surfacing road pavements. In most part of the world, this material has been widely used in various configurations and has been more acceptable than the cement concrete pavement. In America alone, over 93\% of the hard surface roads are made of asphaltic concrete [1]. In Nigeria, over $61,000 \mathrm{~km}$ of roads has been constructed/rehabilitated between 1986 to date [2].

During the service life of road pavement, failure may occur due to stripping, sub-base failure or erosion. As soon as stripping begins, displacement, detachment and pore pressure weakens the pavement causing pot holes, cracking and segregation of the aggregates from the bitumen [3].These failed sections of pavement refer to as pot holes are usually removed and replaced and in some cases, the removal involves the sub-base material to achieve better results. Most of the materials removed during rehabilitation are discarded on landfills or road side causing environmental hazards.

Recycling of used material has been identified as a means to an end toward sustainable development. The recycling process known as Reclaimed Asphalt Pavement (RAP) refers to those recycled pavement materials that are removed or reprocessed during rehabilitation of existing flexible pavement which contains both degraded bituminous materials and aggregates particles[4]. The utilization of RAP materials in new pavement construction has been an advantageby reducing the quantity of waste debris disposed of in landfills and reducing the depletion rate of available natural resources. Taha[5] reported that RAP has become a sustainableroute in road maintenance and rehabilitation by preserving environment, resources, and retaining the existingnatural land forms. Sayed[6] reported that U.S
Environmental Protection Agency in 1993 estimated that over 73 million tons of asphalt material is recycledeach year which is about $80 \%$ of total asphalt pavement removed each year.

Most of the recycling of pavement material is reused in road pavement construction and rehabilitation. Researches are also scars in the area of RAP use in concrete production and maintenance. Concrete being the most used construction material all over the world have aggregate content of over $70 \%$ of it volume. If research of the possibility of utilizing RAP in concrete rather than using new mineral aggregates can be established, most of the our landfills will be lowered, environment would be protected and natural land forms would be sustained and protected.

This paper attempt to investigate the possibility of utilizing RAP as fine aggregate in concrete. Concrete area dominant material in construction industry and its strength and durability being the key parameter was investigated. Utilization of RAP in concrete could serve as an alternative to for disposal towards sustainable development.

\section{Materials}

The RAP material was sourced from the Federal Road Maintenance Agency (FERMA) road repairs construction site along Gombe-Bauchi highway in Nigeria. The material was prepared by milling which was crushed manually and sieved using $5 \mathrm{~mm}$ sieve to [7]. RAP specific gravity of 2.45 was obtained. The sample passing the sieve was used as the replacement for the fine aggregate.

Fine aggregate mainly of naturalriver sand was used in this investigationwhich conformed to the requirement of BS [8]in zone 2 aggregate classification and specific gravity of 


\section{International Journal of Science and Research (IJSR) \\ ISSN (Online): 2319-7064 \\ Index Copernicus Value (2013): 6.14 | Impact Factor (2015): 6.391}

2.72 while the coarse aggregate from crushed mineral rock was used all obtained in Nigeria.

Ordinary Portland cement was used throughout the course of this researchin conformity to ASTM[9] and portable drinking water from running tap was used which was clean and clear while undertaking the research work.

\section{Mix design}

Mix design of 1:2.07:3.11 for cement, fine and coarse aggregate respectively and water cement ratio of 0.5 was used throughout the research program. RAP replacement of fine aggregate at $0,20,40,60,80$ and $100 \%$ was used. Table 1 shows the composition of the constituent materials used.

Table 1: Mix Proportion

\begin{tabular}{|c|c|c|c|c|c|}
\hline $\begin{array}{c}\text { RAP } \\
(\%)\end{array}$ & $\begin{array}{c}\text { Cement } \\
(\mathrm{kg})\end{array}$ & $\begin{array}{c}\text { Fine } \\
\text { aggregate } \\
(\mathrm{kg})\end{array}$ & $\begin{array}{c}\text { Coarse } \\
\text { aggregate } \\
(\mathrm{kg})\end{array}$ & $\begin{array}{c}\text { RAP } \\
(\mathrm{kg})\end{array}$ & $\begin{array}{c}\text { Water } \\
\text { content } \\
(\mathrm{kg})\end{array}$ \\
\hline 0 & 21.90 & 45.30 & 67.95 & 0.00 & 10.95 \\
\hline 20 & 21.90 & 36.24 & 67.95 & 9.06 & 10.95 \\
\hline 40 & 21.90 & 27.18 & 67.95 & 18.12 & 10.95 \\
\hline 60 & 21.90 & 18.12 & 67.95 & 27.18 & 10.95 \\
\hline 80 & 21.90 & 9.06 & 67.95 & 36.24 & 10.95 \\
\hline 100 & 21.90 & 0.00 & 67.95 & 45.30 & 10.95 \\
\hline
\end{tabular}

\section{Experimental Program}

\section{Workability}

Workability test in accordance with BS EN [10] was carried out. The use of RAP as a replacement of fine aggregate showed greater effect on the workability of the concrete. Fig.2 shows the result of the slump test carried out in concrete with a replacement of fine aggregate with RAP. Between $0-20$ and $40-60 \%$ Rap replacements of fine aggregate, no noticeable change workability was observed. $100 \%$ increment was observed at Rap content of $40 \%$ while above $60 \%$ RAP content, $50 \%$ increase in workability was recorded as shown in Fig.1.The increment in workability recorded is due to the bitumen content in the concrete matrix which does not absorb water. The excess water not absorbed by the particles cause the fluidity leading to higher workability. The reason for the constant workability at $0-20$ and $40-60 \%$ could not be substantiated.

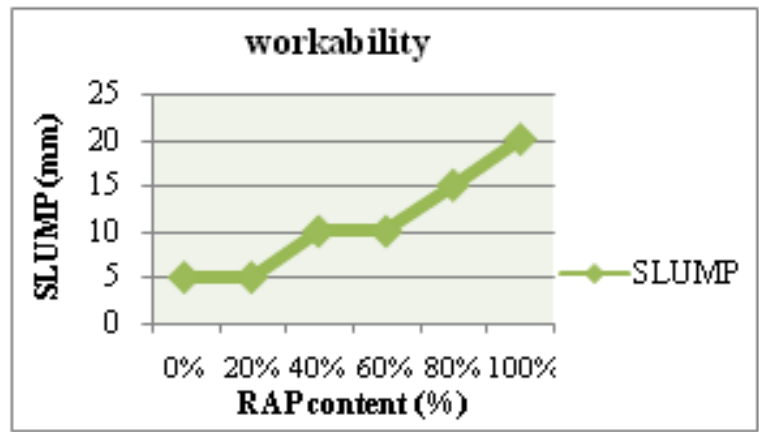

Figure 1: Workability of concrete containing RAP as fine aggregate

\section{Water Absorption}

Water absorption test in conformity with BS [11]:method for determination of water absorption of concrete. RAP content of $20 \%$ showed the best result with an absorption value of $25 \%$ less than the control specimen. The specimen with $40 \%$ RAP content showed the highest absorption value of $6.5 \%$ higher than the control. Fig. 2 shows the result of water absorption of RAP concrete from $0-100 \%$ fine aggregate substitution. Replacement of RAP in excess of $40 \%$ revealed continuous decrease in water absorption value less than that of the control. The reduction in water absorption of concrete containing RAP is due to the air voids created in the matrix preventing water getting access. More so, the replacement of fine aggregates RAP which may fill up voids within the specimen with bituminous tiny particles could also contribute to the water resistance of the specimens.

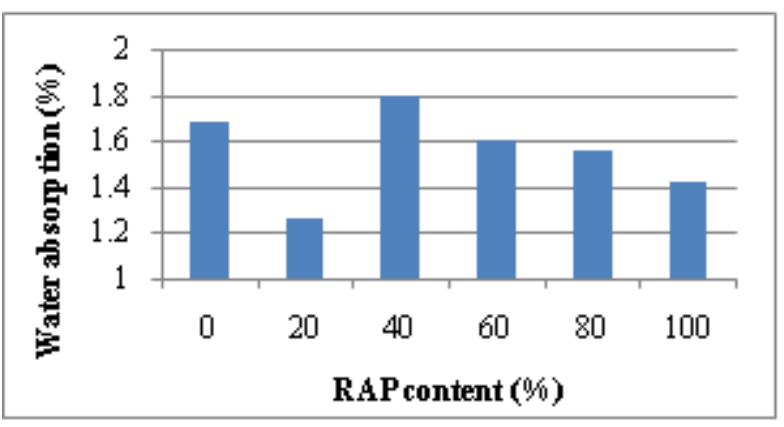

Figure 2: Water absorption of concrete containing RAP as fine aggregate

\section{Density of concrete}

The experiment was carried out in accordance with BS EN [12]: Standard Test Method for Hardened concrete Density. Specimen 18 numbers were used for the determination of density test. The densities of all the samples containing RAP were found to be lower than that of the control specimen as shown in Fig. 3. The density decreases with increase in fine aggregate replacement with RAP. Although, all concrete samples containing 20-100\% RAP aggregate weigh more than $2000 \mathrm{~kg} / \mathrm{m}^{3}$ which outside the category of lightweight concrete specified by Neville [13].

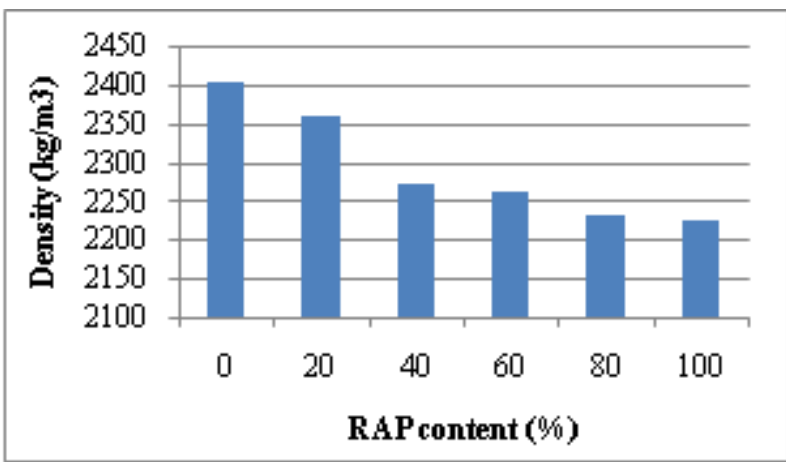

Figure 3: Density of Hardened concrete containing RAP as fine aggregate

\section{Compressive strength}

Compressive strength test was conducted in accordance with the provisions of BS EN [14]: Standard Testing Method for Making and curing specimens for strength tests using sample size $150 \times 150 \times 150 \mathrm{~mm}$ cube. A total of 54 specimens were produced and tested for 3, 7 and 28 days respectively. The curing was carried out in clean water pond 


\section{International Journal of Science and Research (IJSR) \\ ISSN (Online): 2319-7064 \\ Index Copernicus Value (2013): 6.14 | Impact Factor (2015): 6.391}

for the aforementioned period until testing days and the result is shown in Fig. 4.

It was observed that the compressive strength decreases with increase in RAP content for all the curing days. Replacement of RAP up to $40 \%$ did not show significant reduction in the compressive strength of the concrete specimens. A reduction in compressive strength of 4.7 and $5.2 \mathrm{MPa}$ was observed for 20 and $40 \%$ RAP replacements respectively at 28-day. Compressive strength 7-day also showed similar trend with 28-days strength test which is about 3\% less. The 3-days strength revealed a continuous linear reduction in strength with a gradient of about $0.15 \%$. The reduction in strength is due to the ductility of bituminous particles in the RAP which allows compression of the specimen during loading. More so, the ductile behaviour of the RAP particles could also affect the hydration of the cement-aggregate gel thereby reducing it strength.

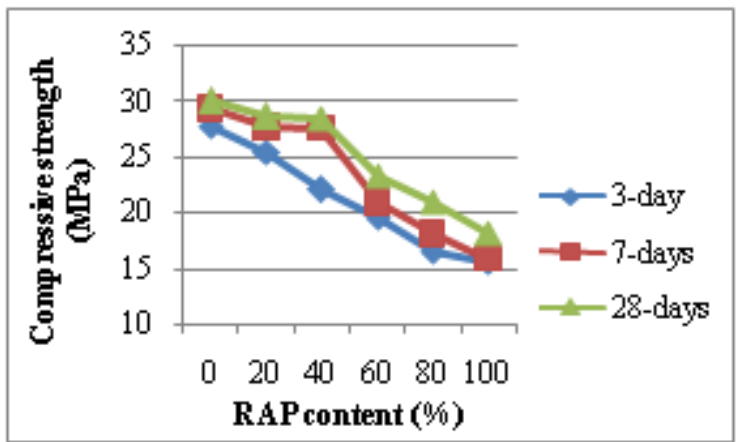

Figure 4: Compressive strength of concrete containing RAP as fine aggregate

\section{Conclusions}

Reclaimed Asphalt Pavement (RAP) was used to replace fine aggregate in concrete at $0,20,40,60,80$ and $100 \%$. Workability, density and compressive strength were carried out on the specimens in line with specific standards. Based on the results obtained, RAP content of up to $40 \%$ was observed to be viable for both density reduction and compressive strength behavior. More research works are required to ascertain the true behavior of RAP concrete such as reducing the water cement ratio with increase in RAP replacement. Also, researches on ductility, impact value and other properties should be carried out.

\section{References}

[1] Amirkhanian, S. N., \& Williams, B. (1993). Recyclability of moisture damaged flexible pavements. Journal of Materials in Civil Engineering, 5(4), 510530.

[2] Filani, M. O. (1993). Transport and rural development in Nigeria. Journal of Transport Geography, 1(4), 248254.

[3] Taylor, M. A., \& Khosla, N. P. (1983). Stripping of Asphalt Pavements. Transportation Research Record, 150-158.

[4] Puppala, A. J., Hoyos, L. R., \& Potturi, A. K. (2011). Resilient moduli response of moderately cement-treated reclaimed asphalt pavement aggregates. Journal of Materials in Civil Engineering, 23(7), 990-998.

[5] Taha, R., Al-Harthy, A., Al-Shamsi, K., \& Al-Zubeidi, M. (2002). Cement stabilization of reclaimed asphalt pavement aggregate for road bases and subbases. Journal of Materials in Civil Engineering, 14(3), 239245.

[6] Sayed, S. M., Pulsifer, J. M., \& Schmitt, R. C. (1993). Construction and performance of shoulders using UNRAP base. Journal of Materials in Civil Engineering, 5(3), 321-338.

[7] BS 410-1 (2000)"Test sieves. Technical requirements and testing. Test sieves of metal wire cloth". British Standard Institution, London.

[8] BS 882(1992).Specification For Aggregates From Natural Sources For Concrete. British Standard, 1-9.

[9] ASTM C150-1 (2001). Standard specification for Portland cementAmerican Society for Testing and Material, Philadelphia, PA.

[10]BS EN12350-2 (2009). Concrete-fresh concrete testsPart, 2, 12350-12352.British Standard Institution, London.

[11]BS 1881-122 (2011). Testing concrete: Method for determination of water absorption. British Standard Institution, London.

[12]BS EN 12390-7 (2009). Testing Hardened Concrete: Density of Hardened Concrete. British Standard Institution, London.

[13] Neville, A. M. (1995). Properties of concrete.

[14]BS EN 12390-2: (2009). Making and curing specimens for strength tests. British Standard Institution, London.

\section{Authors Profile}

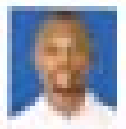

Sani Mohammed Bida: Received Bachelor of Engineering in Civil Engineering from BUK, Kano, Nigeria. Master of Science in Structural Engineering from UPM, Serdang, Malaysia and currently pursuing $\mathrm{PhD}$ in Structural Engineering in UPM, Malaysia.

Muktar Nuhu Danraka: Received Bachelor of Engineering in Civil Engineering from BUK, Kano, Nigeria. Master of Engineering in Structural Engineering from ATBU, Bauchi, Nigeria and currently pursuing $\mathrm{PhD}$ in Structural Engineering in UPM, Malaysia.

Jiya Mohammed Ma'ali: Received Bachelor of Engineering in Civil Engineering from FUT, Minna, Nigeria and Master degree in Structural Engineering from the same university. 